\title{
Diagnostic and Prognostic Value of CD123 in Acute Leukemia
}

\author{
TAGHREED M. KAMAL EL-DIN, M.D.*; GHADEER ABD EL-RAZZAK, M.Sc.*; \\ MAHMOUD YOUSSEF EL-TAHTAWY, M.D.* and HOWAIDA NAFADY, M.D.**
}

The Department of Clinical Pathology, Faculty of Medicine* and Clinical Hematology Unit, Internal Medicine Department, Faculty of Medicine**, Assiut University Hospital, Assiut, Egypt

\begin{abstract}
Background: Abnormalities of the alpha-chain of the interleukin-3 receptor (IL-3RA or CD123) are frequently observed in some leukemic disorders and may contribute to the proliferative character of leukemic cells.

Aims of Study: To study the role of CD123 expression in diagnosis of acute leukemia and correlation with other well established immunophenotyic markers of AML and ALL and evaluate its prognostic impact on outcome of acute leukemic patients.

Patients and Methods: The percentage of CD123 (+) cells in the blast population was determined at diagnosis using flow cytometry; expression $>20 \%$ was considered positive. Thirty two adult patients with acute myeloid leukemia were included in the study. Correlations of CD 123 with expression of CD34, CD117, CD33, CD13, BM blast percentage and for AML outcomes as remission status at the end of the induction, 6 months overall survival were evaluated.*Twenty eight patients with acute lymphoblstic leukemia were included in the study. Correlations of CD123 with expression of CD34, CD 10 and CD 19 for ALL outcomes as remission status at the end of the induction, 6 month overall survival were evaluated.

Results: Regarding AML: Median age at diagnosis was 40.5 years (range $17-80$ years), females were $18(56.3 \%)$. CD123 expression was positive in 19 (59.4\%); median expression was $23.5 \%$ (range $10-87 \%$ ). There were positive correlation between CD123 and CD117 (strong) $\{r=0.8, p=$ $0.00\}$ and CD34 (moderate) $\{r=0.5, p=0.02\}$. CD123 was correlated strongly positive with BM blast percent at diagnosis $(r=0.5, p=0.00)$.CD123 +ve AML patients showed poor response to induction chemotherapy not getting CR (84.2\%) vs CD123-ve AML (53.8\%); $p=0.06$. With median follow-up 6 months, 2 patients relapsed; both were CD123 positive. Five patients died, all were CD123 positive. Regarding ALL: Median age at diagnosis was 28 years (range $1-78$ years); out of 28 patients, $6(21.4 \%$ ) were pediatrics ( $<18$ years) and 22 (78.6\%) adults. Patients with B-ALL were 12 (42.9\%) while T-ALL 16 (57.1\%). CD123 expression was positive in 7/28 ( $25 \%)$; all of them were B-ALL vs. $(0 \%)$ T-ALL; $p=0.001$. Mean of CD123 expression was higher in B-ALL vs. T-ALL, $(p=0.002)$. CD123 +ve B-ALL patients not getting CR (71.4\%) vs. CD123-ve B-ALL (20\%). With median follow-up 6 months,
\end{abstract}

Correspondence to: Dr. Ghadeer Abd El-Razzak, E-Mail: ghadeer.razzak111@hotmail.com one patient relapsed was CD 123 positive. Seven patients died, four were CD123 positive (57.1\%).

Conclusion: ${ }^{*} \mathrm{CD} 123+\mathrm{ve}$ AML patients showed poor response to induction chemotherapy vs. CD123 -ve AML patients. *High expression of CD123, CD34 and CD117 antigen could be a high negative factor for prognosis.

Key Words: CD123 - Acute Myeloid Leukemia (AML) - Acute Lymphoblastic Leukemia (ALL).

\section{Introduction}

LEUKEMIA is a group of neoplastic disorders characterized by the proliferation and accumulation of immature hematopoietic cells in the bone marrow and blood. Leukemia involves the production of abnormal white blood cells which do not function in the same way as normal white blood cells. The leukemic cells continue to grow and divide, eventually crowding out the normal blood cell [1]. The two main types of Acute leukemia are: Acute Lymphocytic Leukemia (ALL), Acute Myeloblastic Leukemia (AML). Each main type of leukemia is named according to the type of cell that is affected (a lymphoid cell or a myeloid cell) and whether the disease begins with a mature or immature cell. There morphological classification includes 3 subtypes for ALL (L1, L2, and L3) and 8 subtypes of AML (M0, M1, M2, M3, M4, M5, M6 and M7) [2].

The diagnosis of leukemia in addition to consider the signs and clinical symptoms of the patient (anemia, infection, easy bruising and bleeding). Blood sample may be examined under the microscope to see if the cells appear abnormal. A sample of the bone marrow may also be obtained to establish the diagnosis. Immunophenotyping become an important tool in establishing the diagnosis and classification of acute leukemias. It is useful in the early detection of minimal residual disease and also have prognostic value [3]. 
IL-3 is a pleiotropic cytokine, mainly produced by activated T-lymphocytes, regulating the function and production of hematopoietic and immune cell. This cytokine was originally termed multi-colony stimulating factor (multi-CSF) for its property to stimulate the development of a wide-range of hematopoietic cells from bone marrow, including basophils, neutrophils, eosinophils, macrophages, erythroid cells, megakaryocytes, and dendritic cells (4).

The Interleukin (IL)-3, IL-5 and GranulocyteMacrophage Colony Stimulating Factor (GM-CSF) Receptor, form a subfamily of membrane receptors, known as the Beta Common $\left(\beta_{c}\right)$ family of cytokines because these three receptors share the common signaling subunit $\beta_{c}$. Each of these three receptors is a heterodimer. Functional mature IL3R alpha (also known as CD123 antigen) is located at the level of the plasma membrane where it forms a molecular complex with the IL-3R beta chain [5]. The gene encoding interleukin-3 receptor is located in the Pseudoautosomal Region (PAR) at the end of the short arm of the $\mathrm{X}$ and $\mathrm{Y}$ chromosome. Alpha-chain of the Interleukin-3 Receptor (IL-3RA or CD123) is overexpressed in leukemic blast cells in various hematologic malignancies, including acute myeloid and B-lymphoid leukemia, Blastic Plasmocytoid Dendritic Neoplasms (BPD$\mathrm{CN}$ ) and hairy cell leukemia While normal hematopoietic stem cells does not express CD123. IL3 receptor was expressed on majority of CD34+ haematopoeitic progenitor cell and its expression is lost during erythroid and megakaryoblastic differentiation and moderately decreased during monocytic differentiation. IL 3 receptor may represent a potentially important target for the development of new antileukemic drugs [6].

\section{Aim of work:}

To study the role of CD123 expression in diagnosis of acute leukemia through correlation with other well established immunophenotyic markers of AML and ALL and evaluate its prognostic impact on outcome of acute leukemic patients.

\section{Patients and Methods}

This work was carried out at the Clinical Pathology Department at Assiut University during the period between May 2016 and March 2017. The study was carried on 60 newly diagnosed acute leukemic patients, recruited from Clinical Hematology Department and outpatient clinic. The patients were newly diagnosed as acute leukemia after Bone marrow Aspirate, cytochemical studies and Immunophenotyping. All patients were subjected to the following:

I- Medical history taking (fever, bleeding, therapeutic history, blood transfusion) and clinical examination including hepatomegaly, splenomegaly and lymphadenopathy assessment.

\section{II- Laboratory investigations:}

A- Complete Blood Counting (CBC) using an automated blood cell counter CELL DYN (1700) with examination of peripheral blood films stained with Leishman stain for differential leukocytic count and detection of circulating malignant blast cells.

B- Examination of Leishman stained BM aspiration smears for assessment of BM cellularity, morphological BM infiltration and cytochemical examination by sudan black B, specific and nonspecific esterase, acid phosphatase and Periodic acid Schiff.

C- Flow Cytometric (FCM) immunophenotypic analysis of BMA was performed using restricted panel of (HLA DR, CD45, Cyto MPO, CD13, CD33, CD34, CD117, CD7, CD10, CD19 as primary panel) and (CD41, CD61, CD14, CD36, Glycophorin A as secondary myeloid panel) and (CD4, CD8, CD7 as secondary lymphatic panel) using (BD FACS scan 4 color flow cytomtery) in addition to Fluorescin Isothiocyanate Labeled (FITC) CD123 (Becton Dickenson).

D- Follow-up of patient by BM blast to predict outcome and prognosis of disease after remission induction therapy and consolidation therapy.

Acquisition and analysis of stained suspension was performed by FACS caliber flow cytometer (Becton Dickinson, USA) and analyzed with the cell quest software acquiring at least 20.000-30.000 cells at a high rate of 400-500 cells/second for each marker. Negative isotype control was run first to identify the position of the negative and the positive populations. At least two plots were drawn during the acquisition of each tube; one of them displayed Forward Scatter (FSc) on X axis versus Side Scatter (SSc) on Y axis to identify the size and granularity of cells and to exclude debris and dead cells. The second plot displayed the antibody marker on $\mathrm{X}$ axis versus FSc. The tube containing CD45 (gating reagent) was analyzed first to set a gate using FSc and SSc patterns and analysis of the sample tubes was performed as follows: Setting cursors for differentiating positive and negative populations (Isotype control plot analysis) so that $98 \%$ of the cells are negative, the marker set on the negative control plot was copied on histogram 
and on each analyzed of markers plots, so dividing it into 4 quadrants. Analysis of the population in each quadrant was as follows: The lower left quadrant; double negative for both markers, the lower right quadrant; positive for $\mathrm{X}$ axis marker only, the upper left quadrant; positive for $Y$ axis marker only and the upper right quadrant; positive for both markers.

\section{Statistical methods:}

Data was analyzed using IBM SPSS Version 20. Numerical data were expressed as mean and standard deviation. Qualitative data were expressed as frequency and percentage. Chi-square test was used to compare the nominal data in different groups. Pearson correlation was used to assess the correlation between CD 123 and other markers. $p$ value was significant if $<0.05$.

\section{Results}

Majority of patients with AML were AMLM4/M5 11 cases (34.2\%) followed by AML-M1/ M2 in 9 cases $(28.1 \%)$. Regarding those patients with ALL; 16 cases (57.1\%) were T-ALL while 12 cases $(42.9 \%)$ were B-ALL.

\section{CD123:}

There was significant difference between the different subtypes of AML regarding frequency of CD $123(p=0.01)$. It was noticed that those patients with AML-M4/M5 (90\%) had the highest level of CD123 expression (51.35 13.01$)$ followed by those with AML-M1/M2 (75\%) with expression level (31 \pm 7.09$)$, while none of patients with AML-M6 was positive for CD123.

Comparison of different outcomes in the study according to level of CD123:

It was noticed that patients who died $40(66.7 \%)$ had significant higher level of CD123 (78.22 \pm 8.23$)$ followed by patients not in remission $5(8.33 \%)$ had level of CD123 $(30.12 \pm 7.23)$ while those who entered remission 15 (25\%) had significant low level of CD123 expression (14.01 \pm 3.33$)$ with $p=$ 0.00 .

Comparison between CD123, CD34, CD117 expression with outcomes of AML patients:

- CD123 +ve, CD34 +ve, CD117 +ve were expressed in 18 cases $(56.2 \%) ; 15$ cases $(83.3 \%)$ from them not in Remission.

- CD 123 -ve, CD34 -ve, CD 117 -ve were expressed in 5 cases $(15.6 \%) ; 3$ cases $(60 \%)$ from them entered remission.

- CD 123 +ve AML patients not getting CR (84.2\%) vs. CD123 -ve AML (53.8\%); $p=0.06$. With median follow-up 6 months, 2 patients relapsed; both were CD 123 positive. Five patients died, all were CD123 positive with statistically significant poor OS $(p=0.04)$.

- CD 123 +ve B-ALL patients not getting CR (71.4\%) vs. CD 123-ve B-ALL (20\%). With median follow-up 6 months, one patients relapsed was CD 123 positive. Seven patients died, four were CD123 positive $(57.1 \%)$ while three were CD123 negative $(60 \%)(p=0.92)$.

Table (1): FAB distribution of AL patient group.

\begin{tabular}{cc}
\hline Diagnosis & Frequency (percentage) \\
\hline$A M L:$ & 9 \\
M1/M2 & $7(28.1 \%)$ \\
M3 & $11(34.2 \%)$ \\
M4/M5 & $3(9.4 \%)$ \\
M6 & $2(6.3 \%)$ \\
M7 & \\
ALL: & $12(42.9 \%)$ \\
B-ALL & $16(57.1 \%)$ \\
T-ALL &
\end{tabular}

Data was expressed in form of frequency (\%).

AML: Acute Myeloid Leukemia.

ALL: Acute Lymphobl astic Leukemia.

Table (2): Immunophenotypic markers in patients with AML according to frequency (percentage).

\begin{tabular}{|c|c|c|c|c|c|c|}
\hline Markers & $\mathrm{M} 1 / \mathrm{M} 2 \quad(\mathrm{n}=9)$ & M3 $(n=7)$ & M4/M5 $(n=11)$ & M6 $(n=3)$ & M7 $(n=2)$ & $p$-value \\
\hline CD 123 & $7(75 \%)$ & $1(14.3 \%)$ & $10(90 \%)$ & 0 & $1(50 \%)$ & $0.01 *$ \\
\hline HLA-DR & $9(100 \%)$ & $7(100 \%)$ & $11(100 \%)$ & $2(66.7 \%)$ & $2(100 \%)$ & 0.34 \\
\hline CD34 & $9(100 \%)$ & $2(28.6 \%)$ & $11(100 \%)$ & $2(66.7 \%)$ & $2(100 \%)$ & $0.00^{*}$ \\
\hline CD117 & $7(75 \%)$ & $2(28.6 \%)$ & $9 \quad(81 \%)$ & $1(33.3 \%)$ & 0 & $0.02 *$ \\
\hline CD45 & $9(100 \%)$ & 0 & $11(100 \%)$ & $3(100 \%)$ & $2(100 \%)$ & $0.00^{*}$ \\
\hline Cyto MPO & $3(25 \%)$ & $3(42.9 \%)$ & $5 \quad(50 \%)$ & 0 & 0 & 0.62 \\
\hline CD33 & $9(100 \%)$ & $7(100 \%)$ & $10(90 \%)$ & $3(100 \%)$ & $1(50 \%)$ & $0.00 *$ \\
\hline CD 13 & $9(100 \%)$ & $7(100 \%)$ & $11(100 \%)$ & $3(100 \%)$ & $2(100 \%)$ & $0.00^{*}$ \\
\hline Megakaryocytic marker (CD41, CD61) & 0 & 0 & 0 & 0 & $2(100 \%)$ & \\
\hline Monocytic marker (CD14, CD36) & 0 & 0 & $11(100 \%)$ & 0 & 0 & - \\
\hline Glycophorin A & 0 & 0 & 0 & $3(100 \%)$ & 0 & - \\
\hline
\end{tabular}


Table (3): Immunophenotypic markers in patients with all according to frequency (percentage).

\begin{tabular}{llll}
\hline Markers & $\begin{array}{l}\text { B-ALL } \\
(\mathrm{n}=12)\end{array}$ & $\begin{array}{c}\text { T-ALL } \\
(\mathrm{n}=16)\end{array}$ & $\begin{array}{c}p \text { - } \\
\text { value }\end{array}$ \\
\hline CD 123 & $7(58.3 \%)$ & 0 & $0.02^{*}$ \\
HLA-DR & $10(83.3 \%)$ & $11(68.8 \%)$ & 0.18 \\
CD34 & $9(75 \%)$ & $6(37.5 \%)$ & $0.01^{*}$ \\
CD45 & $11(91.7 \%)$ & $16(100 \%)$ & 0.24 \\
CD 10 & $12(100 \%)$ & $4(25 \%)$ & 0.23 \\
CD 19 & $11(91.7 \%)$ & $3(18.3 \%)$ & $0.00^{*}$ \\
CD7 & $2(16.7 \%)$ & $4(25 \%)$ & 0.52 \\
CD3 & $1(8.3 \%)$ & $16(100 \%)$ & $0.02^{*}$ \\
CD4 & $1(8.3 \%)$ & $16(100 \%)$ & $0.03 *$ \\
CD8 & $1(8.3 \%)$ & $1 \quad(6.3 \%)$ & $0.04 *$ \\
CD79a & $7(58.3 \%)$ & 0 & $0.02 *$ \\
\hline
\end{tabular}

Data was expressed in form of frequency (\%).

$p$-value was significant if $<0.05$.

CD : Cluster Differentiation.

HLA : Human Leucocytic Antigen.

: Statistically Significant.

Table (4): Level of CD 123 in different outcomes of the study.

\begin{tabular}{ccccc}
\hline $\begin{array}{c}\text { Remission } \\
(\mathrm{n}=15)\end{array}$ & $\begin{array}{c}\text { Not in } \\
\text { remission }(\mathrm{n}=5)\end{array}$ & $\begin{array}{c}\text { Death } \\
(\mathrm{n}=40)\end{array}$ & $\begin{array}{c}p \text { - } \\
\text { value }\end{array}$ \\
\hline CD 123 $14.01 \pm 3.33$ & $30.12 \pm 7.23$ & $78.22 \pm 8.23$ & $0.00^{*}$ \\
\hline
\end{tabular}

- Data was expressed in form of mean $\pm \mathrm{SD}$ and $p$-was significant if $<0.05$.

*: Statistically significant.

Table (5): Comparison between CD123, CD34 and CD117 expression with outcomes of AML patients.

\begin{tabular}{|c|c|c|c|}
\hline & $\begin{array}{l}\text { Total } \\
(\mathrm{n}=32)\end{array}$ & Remission & $\begin{array}{l}\text { Not in } \\
\text { remission }\end{array}$ \\
\hline $\begin{array}{l}\cdot \mathrm{CD} 123+\mathrm{ve}, \mathrm{CD} 34 \\
+\mathrm{ve}, \mathrm{CD} 117+\mathrm{ve}\end{array}$ & $18(56.2 \%)$ & $3(16.6 \%)$ & $15(83.3 \%)$ \\
\hline $\begin{array}{c}\text { - CD123-ve, CD34 } \\
-\mathrm{ve}, \mathrm{CD} 117-\mathrm{ve}\end{array}$ & $5 \quad(15.6 \%)$ & $3(60 \%)$ & $2 \quad(40 \%)$ \\
\hline
\end{tabular}

Data was expressed in form of frequency (\%).

CD: Cluster Differentiation.

Table (6): Univariate analysis of association of CD123 expression with outcomes of AML patients.

\begin{tabular}{lccc}
\hline Event & $\begin{array}{c}\mathrm{CD} 123+\mathrm{ve} \\
(\mathrm{n}=19) \\
\mathrm{N}(\%)\end{array}$ & $\begin{array}{c}\mathrm{CD} 123-\mathrm{ve} \\
(\mathrm{n}=13) \\
\mathrm{N}(\%)\end{array}$ & $\begin{array}{c}p- \\
\text { value }\end{array}$ \\
\hline $\begin{array}{l}\text { Remission: } \\
\text { Yes }\end{array}$ & $3(15.8 \%)$ & $6(46.2 \%)$ & 0.06 \\
$\quad$ No & $16(84.2 \%)$ & $7(53.8 \%)$ & \\
$\begin{array}{l}\text { Survival at 6 months: } \\
\quad \text { Alive }\end{array}$ & & & \\
$\quad$ Dead & $14(73.7 \%)$ & $13(100 \%)$ & $0.04 *$ \\
Relapse: & $5(26.3 \%)$ & $0(0 \%)$ & \\
$\quad$ Yes & & & \\
$\quad$ No & $2(10.5 \%)$ & $0(0 \%)$ & 0.22 \\
\hline
\end{tabular}

Table (7): Univariate analysis of association of CD123 expression with outcomes of ALL patients.

\begin{tabular}{lccc}
\hline Event & $\begin{array}{c}\mathrm{CD} 123+\mathrm{ve} \\
(\mathrm{n}=7)\end{array}$ & $\begin{array}{c}\mathrm{CD} 123-\mathrm{ve} \\
(\mathrm{n}=5)\end{array}$ & $\begin{array}{c}p \text { - } \\
\text { value }\end{array}$ \\
\hline $\begin{array}{l}\text { Remission: } \\
\quad \text { Yes }\end{array}$ & $2(28.6 \%)$ & $4(80 \%)$ & 0.07 \\
$\quad$ No & $5(71.4 \%)$ & $1(20 \%)$ & \\
Survival at 6 months: & & & \\
$\quad$ Alive & $3(42.9 \%)$ & $2(40 \%)$ & 0.92 \\
$\quad$ Dead & $4(57.1 \%)$ & $3(60 \%)$ & \\
Relapse: & & & \\
$\quad$ Yes & $1(14.3 \%)$ & $0(0 \%)$ & 0.37 \\
$\quad$ No & $6(85.7 \%)$ & $5(100 \%)$ & \\
\hline
\end{tabular}

Data was expressed in form of frequency $(\%)$ CD: Cluster Differentiation.

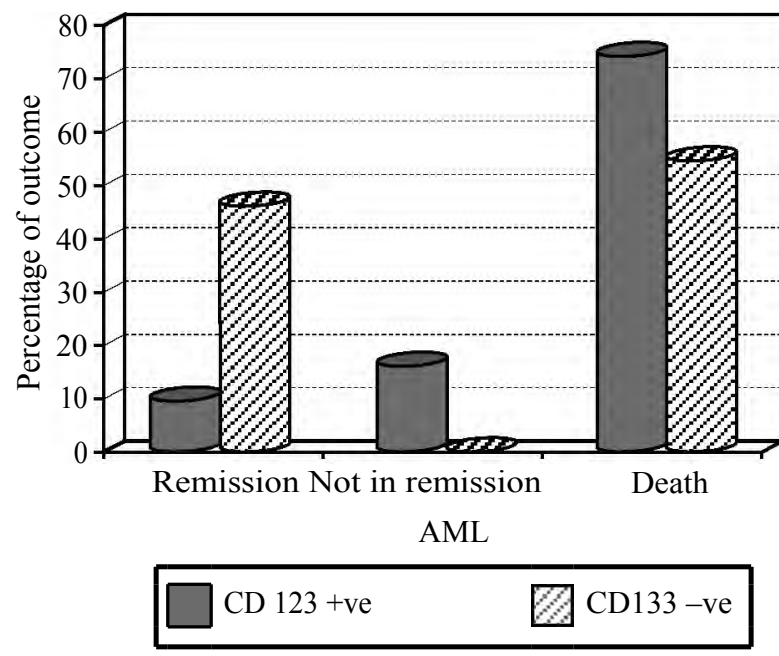

Fig. (1): Comparison between CD123 expression with outcomes of AML patients.

Data was expressed in form of frequency (\%). CD: Cluster Differentiation.

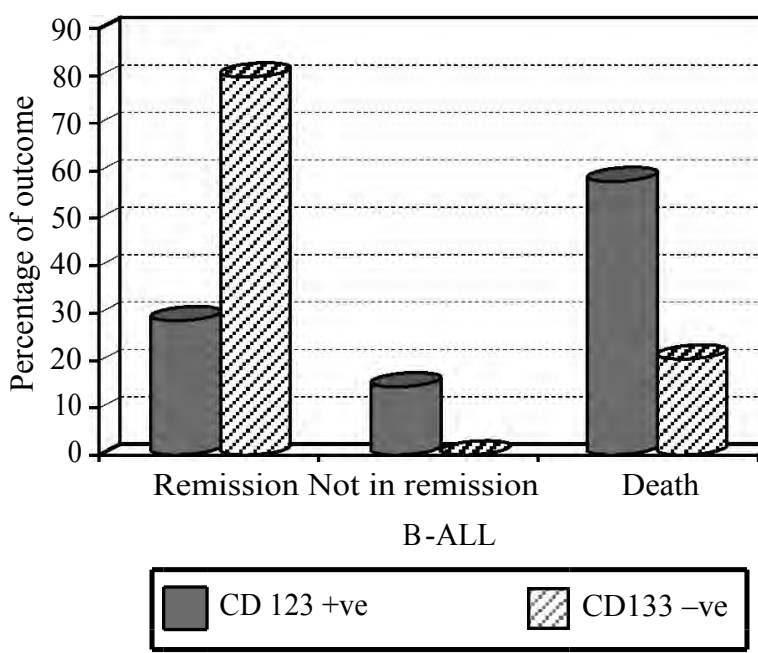

Fig. (2): Comparison between CD123 expression with outcomes of B-ALL patients. 
Table (8): Multivariate regression analysis of bad prognosis in patients with acute leukemia.

\begin{tabular}{lccc}
\hline Markers & $\begin{array}{c}\text { Odd's } \\
\text { ration }\end{array}$ & $95 \%$ CI & $\begin{array}{c}p \text { - } \\
\text { value }\end{array}$ \\
\hline CD 123 (+ve) & 2.55 & $1.22-3.66$ & 0.02 \\
CD123 and CD34 (+ve) & 4.03 & $2.34-4.65$ & 0.04 \\
CD117, CD34 and CD123 (+ve) & 5.24 & $3.62-6.11$ & 0.03 \\
\hline$p$-value was significant if <0.05. & & & \\
CI : Confidence Interval. & & & \\
+ve : Positive. & & & \\
\end{tabular}

\section{Discussion}

In our study, 32 cases (53.3\%) were classified as AML while 28 cases (46.6\%) were classified as ALL, which was explained with high number of AML cases admitted to hospital this agree with Dalia A et al., [7] which were a retrospective studies.

In our study, the commonest FAB AML subtype was AML-M4/M5 11 cases (34.2\%) followed by AML-M1/M2 9 cases (28.1\%), least AML subtype was AML-M7 2 cases $(6.3 \%)$, this agree with Dalia A et al., [7] which reported that commonest FAB AML subtype was AML-M4/M5 (34.5\%) followed by AML-M1/M2 (23.9\%), least AML subtypes were AML-M7 and AML-M6 (2.6\%) (1.8\%) respectively [7], and this disagree with Ghosh et al., [8], in which that commonest FAB AML subtype was AML-M1/M2 (40.5\%) followed by AMLM4/M5 (19.9\%), also disagree with Ihsan M et al., [9] in which AML-M0 was most frequent AML subtype (27.6\%), this variation between studies could be explained by the geographical variation in different countries [9].

Regarding AML: CD123 With regard to its level by FAB subtypes, CD123 was highly expressed in AML-M4/M5 (90\%) followed by AMLM1/M2 (75\%) whereas expressed somewhat lower levels in AML-M7 (50\%) but lowest level expressed in AML-M3 and AML-M6 (14\%), (0\%) respectively and explained that CD123 expression is rapidly lost during erythroid and megakaryocytic differentiation, moderate decreased in monocytic differentiation and sustained in granulocytic lineage, and this agree with previous studies Testa et al., [10].

Regarding ALL: CD123 with regard to its level by FAB subtypes, CD123 was expressed in B-ALL 7 cases $(58.3 \%)$, in contrast all T-ALL cases in this study were negative for CD123, this agree with Testa et al., [10].

The CD123 expression is highly correlated with leucocytic count and percentage of BM blast, this agree with other previous studies Fanmei et al.,
[11] and Dalia A et al., [7] in Mansoura study, this explained by over expression of CD123 can promote proliferation of cells and accelerate leukemic process [11]

The remission rate is much lower in patients with CD123, CD34 and CD117 antigen-positive expression (11.5\%) than negative ones (70\%). High expression of CD123, CD34 and CD117 antigen could be a high negative factor for prognosis, this found agree with other previous studies Nana et al., [12]

\section{Conclusion:}

- CD123 +ve AML patients showed poor response to induction chemotherapy not in Remission vs. CD123 ve AML patients.

- CD123 +ve ALL patients showed poor response to induction chemotherapy not in remission vs. CD123-ve ALL patients.

- High expression of CD123, CD34 and CD117 antigen could be a high negative factor for prognosis.

- CD123 expression may become one of the important factors used to characterize leukemia blasts and predict the prognosis of AML.

\section{Financial support: No financial support.}

Conflicts of interest: There are no conflicts of interest.

\section{References}

1- WEINSTEIN H.J. and PUI C.H.: Childhood Leukemias. UK: Cambridge University Press, 2014.

2- BENNETT J.M., CATOVSKY D., DANIEL M.T., FLANDRIN G., GALTON and GRALNICK H.T.: Proposal for the classification of the acute leukemias French-AmericanBritish (FAB) co-operative group. British Journal of Haematology, 2008.

3- CLAUDIO and ORTOLANI: Flow Cytometry of Hematological Malignancies Wiley BlackWell publication, 2011.

4- DÖHNER K. and DÖHNER: Molecular characterization of acute myeloid leukemia. Haematologica, 93: 976 82, 2008.

5- MUNOZ L., NOMDEDEU J.F., LOPEZ O., CORNIER M.J., BELLIDO M., AVENTIN and SIERRA J.: Interleukin-3 receptor alpha chain (CD123) is widely expressed in hematologic malignancies, 2004.

6- RICCIONI R., ROSSINI A., CALABRÒ L., DIVERIO D., PASQUINI L., LOCOCO F., PESCHLE C. and TESTA U.: Immunophenotypic features of acute myeloid leukemias overexpressing the interleukin 3 receptor alpha chain Leukemia \& lymphoma, 2004. 
7- DALIA A.S., SHERIN M. and ABD EL-AZIZ: Flowcytometric Immunophenotypic Profile of Acute Leukemia: Mansoura Experience, 28 (2): 89-96. Doi 10.1007/s 12288011-0110-2, 2012.

8- GHOSH S., SHINDE S.C., KUMARAN G.S., SAPRE R.S., DHOND S.R., BADRINATH Y., ANSARI R., KUMAR A., MAHADIK S., CHOUGULE A.B. and NAIR C.N.: Haematologic and immunophenotypic profile of acute myeloid leukemia: An experience of Tata Memorial Hospital. Ind. J. Cancer, 40 (2): 71-6, 2009.

9- IHSAN, REGO M., PINHEIRO G., METZE K. and LORAND-METZE I.: Acute leukemias comparison with features observed in other regions of Brazil. Braz J. Med. Biol. Res., 36: 331-7, 2008.
10- TESTA U., PELOSI E. and FRANKEL A.: CD123 is a membrane biomarker and a therapeutic target in hematologic malignancies, 2014.

11- FANMEI G.E., BAOLI and XUEMEI: Immunophenotypes and prognosis of acute leukemia in elderly patients, 7 (10): 3714-8, 2014.

12- NANA, OMRAN H.A., SHABANI M., SHAHRESTANI T., SARAFNEJAD A., KHOSHNOODI J., VOSSOUGH P., FARANOUSH M., SHARIfiAN R.A., JEDDITEHRANI M. and RABBANI H.: Immunophenotypic subtyping of leukemic cells from Iranian patients with acute lymphoblastic eukaemia: Association to disease outcome. Iran J. Immunol., 4: 15, 2007.

\title{
القيمة التشخيصية والتثبؤية للمجمومومة المهيزة (CD123)

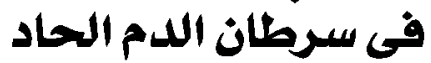

\author{
1- دراسة الآنماط المناعية الظاهرية في حالات سرطان الدم الحادة.
}

Y- دراسة العلاقة بين المجموعة المتميزة بrا كعلامة جديدة مع الآنماط المناعية الظاهرية الآخرى فى حالات سرطان الدم الحادة.

الطرق والوسائل : وآجريت الدراسة على مرضى سبرطان الدم الحاد بقسم آمراض الدم في مستشفيات جامعة آسيوط وكانت عدد الحالات . 7 حالة من سرطان الدم الحاد.

وقد خضعت جميى الحالات في هدا البحث إلى ما يلى:

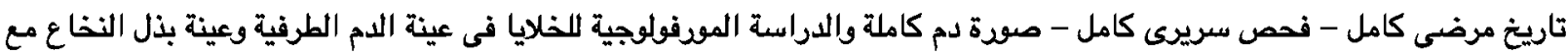

دراسة الكيمياء الخلوية - التذفق الخلوى الروتينى لحالات سرطان الدم الحاد بالإضافة إلى المجموعة المميزة 123.

- جميع حالات إيضضاض الدم الليمفاوى الحاد-T سلبية المجموعة المميزة CD123 لذلك يمكن إستخدام (CD123 الإيجابى) كعلامة لإقصاء

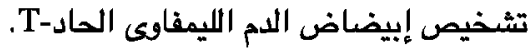

- آظهر مرضى (CD123 إيجابية) إستجابة ضعيفة للعلاج الكيميائى مقارنة للمرضى (CD123 سلبى) فى إبيضاض الدم الميلاوى الحاد. - المجموعة المميزة 123 واحد من العوامل الهامة المعتخدمة فى وصف إنتكاسات سرطان الدم والتبؤ بالقيمة السلبية والإستجابة للعلاج. 